for sea-level change is not supported. The Quaternary world, with its extensive polar icecaps and well-oxygenated ocean, is an unreliable guide to most of Phanerozoic time.

It is clear that we are witnessing a mass extinction that is almost entirely the result of human activities. Eldredge is surely right that this is largely the consequence of habitat destruction rather than direct slaughter, but the consequences are nonetheless dire for cur own species as well as others. Conservation is more than just a matter of saving the odd squirrel species. To echo the words of a recent disenchanted US Secretary of the Interior, it involves the management of entire ecosystems, which falls in the sphere of politics as much as science.

A. Hallam is in the School of Earth Sciences, University of Birmingham, Birmingham B15 $2 \pi$, UK.

\title{
Sceptical inquiries of old
}

\section{Jeremy A. Sabloff}

Fantastic Archaeology: The Wild Side of North American Prehistory. By Stephen Williams. University of Pennsylvania Press: 1991. Pp.432. \$28.95, £27.50 (hbk); $\$ 14.95$, £11.95 (pbk).

NEARLY three decades ago, the late Robert Wauchope, in his brilliant book Lost Tribes and Sunken Continents (University of Chicago Press, 1962), wrote that in response to the widespread popularity of the work of pseudoscientists, "the average professional anthropologist cannot or will not write the kind of book that people in great numbers will want to read". Fortunately, in the years since Wauchope made that damning statement, a growing number of practising scientists have entered the public fray. Fantastic Archaeology by Stephen Williams, Peabody Professor of North American Archaeology and Ethnology at the Peabody Museum, Harvard University, is a superb example of this recent trend. Engagingly written, the book's clear discussion of a variety of archaeological controversies is readily accessible to the general reader and should be of interest to both lay people and professional scholars alike.

More than any other discipline, archaeology has been unsuccessful in convincing the public at large that there is a clear line between the writings and conclusions of professional scholars and amateur dabblers. Although Williams does not closely examine the cultural reasons for this problem nor the huge

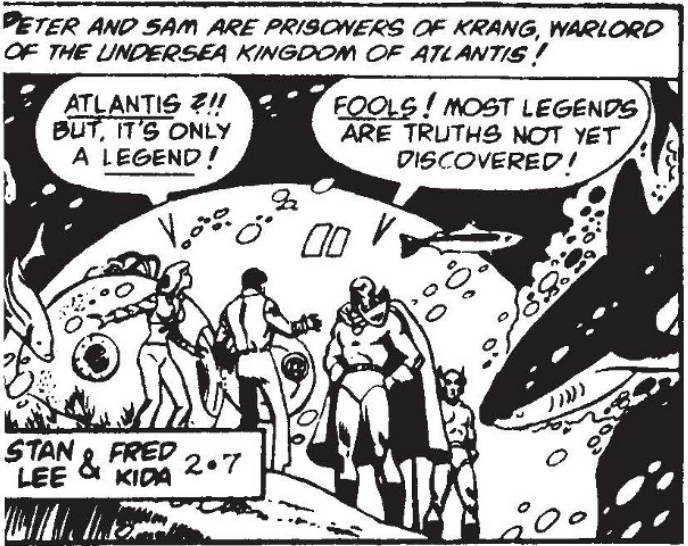

328

origins of North American archaeology and the main intellectual debates of the nineteenth century, Williams forges on to examine a host of fascinating and controversial topics, including famous frauds such as the Grave Creek Stone, the Cardiff Giant and the Davenport Tablets; Constantine Rafinesque and the Walam Olum legend; claims for early Ice Age finds; the supposed lost islands of Atlantis and $\mathrm{Mu}$ and their advocates, particularly Ignatius Donnelly, Helena Blavatsky and the Theosophical Society, and James Churchward; archaeology and religion; alleged Viking finds such as the Kensington Stone and the Newport Tower; assertions of Asian influences on ancient North America with special attention to the writings of Harold Gladwin; the 'decipherments' of averred prehistoric inscriptions by writers such as Barry Fell; and the pronouncements of psychics such as Edgar Cayce, Jeffrey Goodman and Stephen Schwartz.

Williams concludes with a synopsis of does offer one of the best descriptions

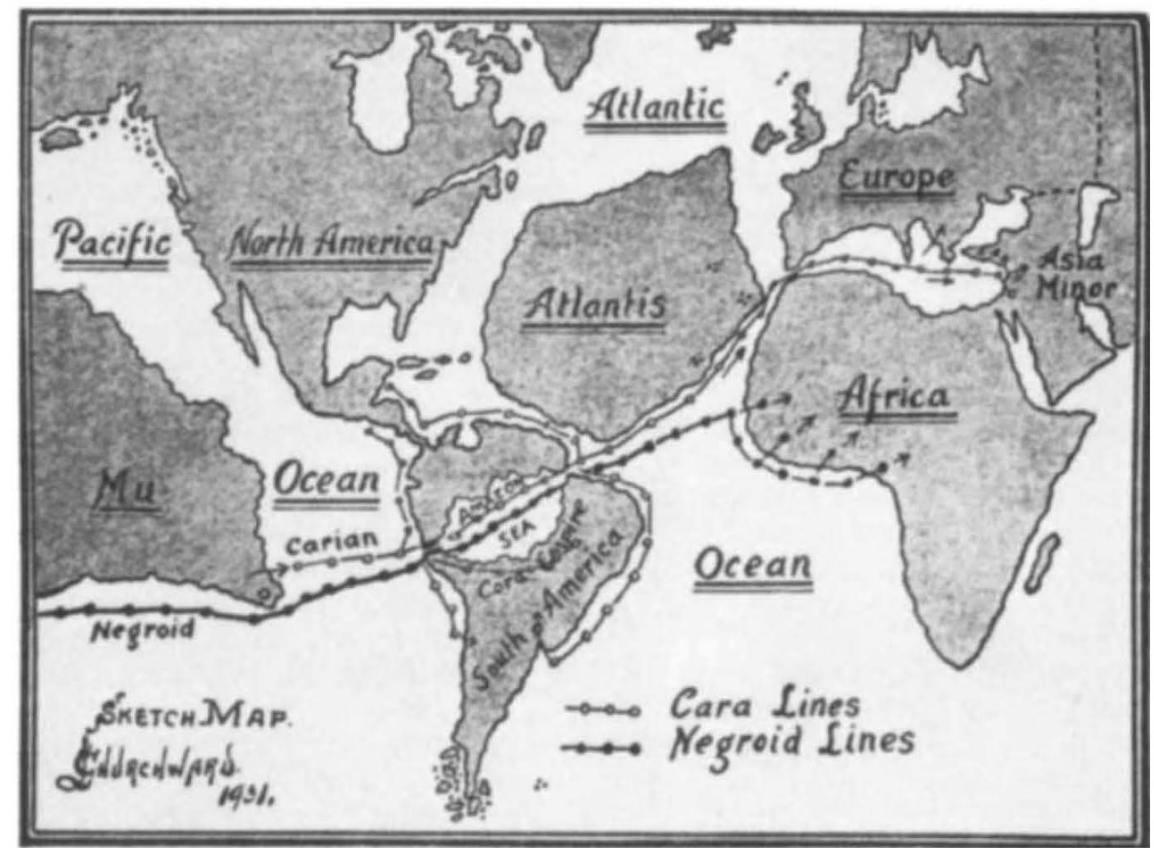

Sunken continents - Churchward's map of Atlantis and Mu, showing Mu's lines of influence on the whole picture of "man's advent on Earth", as he put it.

available of the differences between archaeological and fantastic accounts of various aspects of North American prehistory. He defines fantastic archaeology at the start as "those alternative views of the past that use data and interpretation that will not stand close scrutiny" and proceeds to offer a useful and tolerant overview of its nature and practitioners. The procedures of these purveyors of myth and fantasy are tellingly contrasted with those of trained archaeologists and the latter's use of the scientific method. In addition, the general criteria by which archaeological hypotheses (or assertions) of all stripes can be evaluated are concisely outlined.

Then, after a lucid discussion of the what he calls "the real fantasy", the scientifically reconstructed history of the cultural achievements of the Native American inhabitants of North America. $\mathrm{He}$ maintains that the latter story has as many exciting and intriguing elements as the concocted histories of the pseudoscientific cranks. Archaeologists must strive to make the public aware of this story, Williams convincingly argues, while continuing to be "skeptical inquirers after knowledge and relentless foes of fraud and unreason".

Jeremy A. Sabloff is in the Departments of Anthropology and the History and Philosophy of Science, University of Pittsburgh, Pittsburgh, Pennsylvania 15260, USA. 